\title{
High prevalence of hepatitis $A$ in indigenous population in north Brazil
}

\author{
Vanessa Salete de Paula', Flavio Augusto Pádua Milagres², Guilherme de Macêdo Oliveira², \\ Juliana Custódio Miguel ${ }^{4}$, Helena Medina Cruz ${ }^{4}$, Leticia de Paula Scalioni ${ }^{4,5}$, Vanessa Alves Marques ${ }^{4}$, Monica de \\ Avelar Figueiredo Mafra Magalhães ${ }^{6}$, Anselmo Rocha Romão ${ }^{6}$, Renata Gracie ${ }^{6}$ and Livia Melo Villar ${ }^{4^{*}}$ (0)
}

\begin{abstract}
Objectives: Little is known about hepatitis A virus (HAV) prevalence in indigenous communities. This study aims to evaluate the prevalence of HAV in indigenous community compared to urban population located at Western Amazon in Brazil.

Results: A total of 872 serum samples were obtained from 491 indigenous and 381 non indigenous individuals aging 0 to 90 years. Samples were tested for total and IgM anti-HAV and positive IgM samples were tested for HAV RNA. The overall prevalence of total anti-HAV was $87 \%$, increased according age showing $100 \%$ of prevalence in those aging more than 30 years $(p<0.0001)$ and it was similar among indigenous and urban population. Total anti-HAV prevalence varied between tribes $(p<0.0001)$ and urban sites $(p=0.0014)$ and spatial distribution showed high prevalence in homes that received up to 100 dollars. IgM anti-HAV prevalence was $1.7 \%$ with predominance in males, those aging more than 41 years. No HAV RNA was detected. In conclusion, high overall anti-HAV prevalence was found in indigenous communities in North Brazil demonstrating the importance of universal vaccination in this group.
\end{abstract}

Keywords: Hepatitis A, Prevalence, Indigenous population, Vaccination

\section{Introduction}

In indigenous communities, the risk of infection by hepatitis A virus (HAV) is great, due to the poor sanitation conditions, non-potable water and frequent person-toperson contact that favor the occurrence of outbreaks [1]. Few studies have reported the prevalence of HAV in the indigenous community and values above $96 \%$ was observed in indigenous population in Brazil and Ecuador $[1,2]$.

Apinajé is an indigenous population located in the Western Brazilian Amazon since the eighteenth century in northern region of Tocantins and Araguaia rivers. This

\footnotetext{
*Correspondence: liviafiocruz@gmail.com; Ivillar@ioc.fiocruz.br

${ }^{4}$ Laboratory of Viral Hepatitis, Oswaldo Cruz Institute, FIOCRUZ, Helio and Peggy Pereira Pavillion, Ground Floor, Room B09, FIOCRUZ Av. Brasil, 4365 - Manguinhos, Rio de Janeiro 210360-040, Brazil

Full list of author information is available at the end of the article
}

population include about 1409 indigenous people divided in 15 villages in $1500 \mathrm{~km}^{2}$ [3, 4]. There is a lack of data about HAV epidemiology in these communities that continue to have higher morbidity and mortality from many infectious diseases compared with the general populations in their countries $[2,5,6]$.

This study aims to evaluate the prevalence of hepatitis A infection among an indigenous population of Apinajé ethnic located in Eastern Brazilian Amazon compared to urban population.

\section{Main text \\ Methods}

A cross-sectional study was conducted using a nonprobability sampling method among Amerindians and non-Amerindians living in Eastern Amazon. Blood samples were collected after the approval of the Research Ethics Committee and the National Research

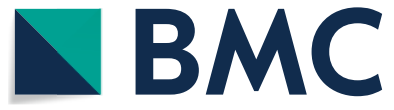

(c) The Author(s) 2020. This article is licensed under a Creative Commons Attribution 4.0 International License, which permits use, sharing, adaptation, distribution and reproduction in any medium or format, as long as you give appropriate credit to the original author(s) and the source, provide a link to the Creative Commons licence, and indicate if changes were made. The images or other third party material in this article are included in the article's Creative Commons licence, unless indicated otherwise in a credit line to the material. If material is not included in the article's Creative Commons licence and your intended use is not permitted by statutory regulation or exceeds the permitted use, you will need to obtain permission directly from the copyright holder. To view a copy of this licence, visit http://creativeco mmons.org/licenses/by/4.0/. The Creative Commons Public Domain Dedication waiver (http://creativecommons.org/publicdomain/ zero/1.0/) applies to the data made available in this article, unless otherwise stated in a credit line to the data. 
Ethics Commission (CAAE: 32789914.6.0000.5248). In the village there was a responsible person (nurse or social worker) for providing data relating to individuals, such as date of birth and registration name. Blood samples were collected after clarifying the purpose of the study to each individual or guardian and the signature (written or digital) in the informed consent form. Eligibility criteria for participation of this study were: residence in the area and the provision of informed consent. Exclusion criteria were: confusion at the time of recruitment and disagreement with the terms of the informed consent.

According census of IBGE [7], there are 1768 indigenous in Tocantinópolis county. There is poor access to water and sanitation. Indigenous population are composed by the following communities: Girassol, Mariazinha, Riachinho, Prata, Serrinha, Folha Grossa. Non indigenous population are composed by Cacau, Mumbuco, Folha Grossa, Fazenda Bela Vista, Urban area Block 18, Urban area Block 22, Tocantinopolis Downtown.

Sample calculation was made using prevalence of total anti-HAV of $80 \%$ and degree of confidence of $95 \%$ with $\alpha$ of 0.05 and critical value of $Z \alpha / 2$ equal to 1.96 . Considering, a population of 2591 individuals in the county, the minimal sample should be 225 individuals.

Blood samples were collected by venipuncture $(10 \mathrm{~mL})$ in tube without anticoagulants and stored on ice to transport to the laboratory. In the laboratory, the blood was centrifuged at $3500 \mathrm{rpm}$ at $25^{\circ} \mathrm{C}$ for $5 \mathrm{~min}$. The supernatant was placed in previously identified microtubes with the registration number and stored at $20{ }^{\circ} \mathrm{C}$, until processed at Viral Hepatitis Laboratory-Fiocruz/RJ.

Total and IgM anti-HAV antibodies were detected using commercial enzyme-linked immunosorbent assay according to the manufacturer's instructions using (ETI-AB-HAVK Diasorin ${ }^{\circledR}$ PLUS). Samples found to be negative on preliminary screening were considered seronegative. Samples that initially tested borderline or positive were retested using ELISA to confirm the results.

Positive IgM anti-HAV samples were submitted to TaqMan RT-PCR assay to quantify HAV genome as previously described [8-10]. RNA was extracted using Qiamp RNA viral mini kit (Qiagen). Reverse transcription and real time reaction were made using master mix containing $1 \times$ SuperScript $^{\text {TM }}$ III RT/Taq master mix (Invitrogen, Hammonton, NJ) and $1.25 \mu \mathrm{L}$ of the assay mixture (300 nM of each primer, $150 \mathrm{nM}$ probe) (Thermo, Assay, Foster City, CA). The synthetic curve, primers and probe were described previously $[8,10]$.

The socioeconomic variables for calculating the indicators proportion of monthly income per household were taken from the demographic census were taken from the population census 2010 [7].
Each individual gave information regarding age, gender and residential location and these data were included along to serological results into (Microsoft Excel) data spreadsheets. Prevalence was calculated for HAV and descriptive statistics were generated for the data.

The spatial representation of anti-HAV total and socioeconomic variables were based on cartography of the digital mesh of the 2010 census [7] and data of antiHAV total according localities of the municipality of Tocantinópolis in the state of Tocantins. For the adaptation of the analyzed locations to the census tracts, the National Register of Addresses for Statistical Purposes of the IBGE was used [7]. Thematic maps of HAV was created using the Geographic Information System (GIS) ArcGis version10.4.

\section{Results}

In the present study, 872 individuals were included aging 0 to 90 years, 491 were Indigenous and 381 were nonindigenous. Most of them were females (53.3\%) and mean age of individuals was $27.4 \pm 20.6$ years. The socio-demographic characteristics of the 872 individuals included in this study are shown in Table 1.

Total anti-HAV prevalence was $87 \%$ (757/872) where prevalence up to $50 \%$ was observed in individuals aging below 5 years and $100 \%$ of prevalence was found in those aging more than 30 years showing statistical significance $(\mathrm{p}<0.0001)$. Total anti-HAV was detected in 433 Indigenous $(88.2 \%)$ and 324 urban population $(85.0 \%)$ and it was not statistically significant $(\mathrm{p}=0.189)$. Gender was not associated to anti-HAV prevalence $(\mathrm{p}=0.05)$. Total anti-HAV prevalence varied between tribes $(\mathrm{p}<0.0001)$ and between urban sites $(\mathrm{p}=0.0014)$. In indigenous population, the lowest prevalence was found in Mariazinha village and among non-indigenous population, the lowest prevalence was found in Bela Vista Urban area.

In Fig. 1, it was possible to observe that the highest total anti-HAV prevalence was observed in Prata village (96.0\%) and Tocantinópolis downtown (96.1\%) and the lowest prevalences were found in Mariazinha Village (74.2\%) and Bela Vista Urban area (66.6\%). Spatial distribution showed high prevalence of total anti-HAV in homes that received up to 500 reais (about 100 dollars) (Fig. 2).

IgM anti-HAV was detected in 15 individuals giving a prevalence of $1.7 \%$. Among 15 acute cases, most of them were males (10/15), aged more than 41 years old and (10/15) lived at Folha Grossa Village (13/15). Real time PCR was done in positive IgM anti-HAV samples and all of them tested negative for HAV RNA. 
Table 1 Hepatitis A virus markers among individuals from Amerindians tribes and urban areas of Tocantinopolis city

\begin{tabular}{|c|c|c|c|}
\hline & Number tested $(n=872)$ & anti-HAV + $(n=757)$ & $H A V \lg M+(n=15)$ \\
\hline Total population studied & $872(100 \%)$ & $757(87.0 \%)$ & $15(1.7 \%)$ \\
\hline \multicolumn{4}{|l|}{ Sex } \\
\hline Female & $467(53.5 \%)$ & $415(88.8 \%)$ & $05(1.1 \%)$ \\
\hline Male & 405 (46.5\%) & $342(84.4 \%)$ & $10(2.4 \%)$ \\
\hline \multicolumn{4}{|l|}{ Age group (years) } \\
\hline 0 a 2 & 52 & $18(34.6 \%)$ & $0(0.0 \%)$ \\
\hline 3 a 5 & 72 & $33(45.8 \%)$ & $0(0.0 \%)$ \\
\hline 6 a 12 & 137 & $110(80.2 \%)$ & $0(0.0 \%)$ \\
\hline 13 a 21 & 170 & $159(93.5 \%)$ & $2(1.2 \%)$ \\
\hline 22 a 30 & 132 & $128(96.9 \%)$ & $1(0.75 \%)$ \\
\hline 31 a 40 & 99 & $99(100.0 \%)$ & $2(2.0 \%)$ \\
\hline 41 a 50 & 69 & $69(100.0 \%)$ & $3(4.3 \%)$ \\
\hline 51 a 60 & 58 & $58(100.0 \%)$ & $1(1.7 \%)$ \\
\hline$>$ de 61 & 83 & $83(100.0 \%)$ & $6(7.2 \%)$ \\
\hline \multicolumn{4}{|l|}{ Location } \\
\hline \multicolumn{4}{|l|}{ Indigenous } \\
\hline Prata village & 51 & 49 (96.0\%) & $0(0.0 \%)$ \\
\hline Girassol village & 66 & $63(95.5 \%)$ & $0(0.0 \%)$ \\
\hline Mariazinha village & 155 & $115(74.2 \%)$ & $0(0.0 \%)$ \\
\hline Riachinho village & 18 & $16(88.8 \%)$ & $0(0.0 \%)$ \\
\hline Serrinha village & 64 & $60(93.7 \%)$ & $0(0.0 \%)$ \\
\hline Folha Grossa village & 137 & $130(94.9 \%)$ & $13(9.5 \%)$ \\
\hline \multicolumn{4}{|l|}{ Non-indigenous (urban areas) } \\
\hline Cacau urban area & 62 & $48(77.4 \%)$ & $1(1.6 \%)$ \\
\hline Mumbuco urban area & 83 & $70(84.3 \%)$ & $0(0.0 \%)$ \\
\hline Urban area block 18 & 84 & $76(90.5 \%)$ & $1(1.2 \%)$ \\
\hline Urban area block 22 & 62 & $47(75.8 \%)$ & $0(0.0 \%)$ \\
\hline Bela Vista urban area & 12 & $8(66.6 \%)$ & $0(0.0 \%)$ \\
\hline Tocantinopolis downtown & 78 & 75 (96.1\%) & $0(0.0 \%)$ \\
\hline
\end{tabular}

\section{Discussion}

The present study gives new information about HAV prevalence in indigenous population before universal HAV immunization in Brazil. Historical accounts indicate that all Apinajé indigenous have contact with Luso-Brazilian since the seventeenth century. In the present study, total anti-HAV prevalence among indigenous was $88.2 \%$, almost the same found in urban population $85 \%$, suggesting a pattern of homogeneous dispersion between both groups. Among Brazilian indigenous population, few studies reported HAV infection where prevalences varies from 93.7 to $100 \%$ [1, 11-13]. An earlier study in Brazil observed that indigenous aging less than 50 years from Parakana Bom Jardim village, who have never been in contact with Portuguese descent, showed no seropositive for HAV, while all indigenous (Novo Parakanã and Asurini Trocará) that had contact with Luso-Brazilian were soropositivity to HAV [12].
In the present study, there was a drop in total anti-HAV prevalence in children aging above 6 years and 100\% of individuals aging more than 40 years were anti-HAV positive. Children aging 0 to 5 years had $41.1 \%$ of HAV prevalence what is lower than found among studies conducted in 2011 at children 1 to 4 years of age (16.67\%) and in 2010 at children aging 1 to 5 years (22.4\%) both located in North Region of Brazil [14, 15].

Total anti-HAV prevalences above $90 \%$ was found in indigenous tribes and non- indigenous settings demonstrating that infection is dispersed in this region. Lin et al. [16] demonstrated an overall prevalence of $98.1 \%$ of anti-HAV in indigenous from Taiwan and this rate did not differ between villages or gender, showing wide HAV dispersion between these locations. High prevalence of HAV was also observed in other indigenous population before universal immunization. Tsou et al. [17] found annual incidence of 2.96/100,000 inhabitants and this value dropped to $0.3 / 100,000$ between 1995 to 2008 in 


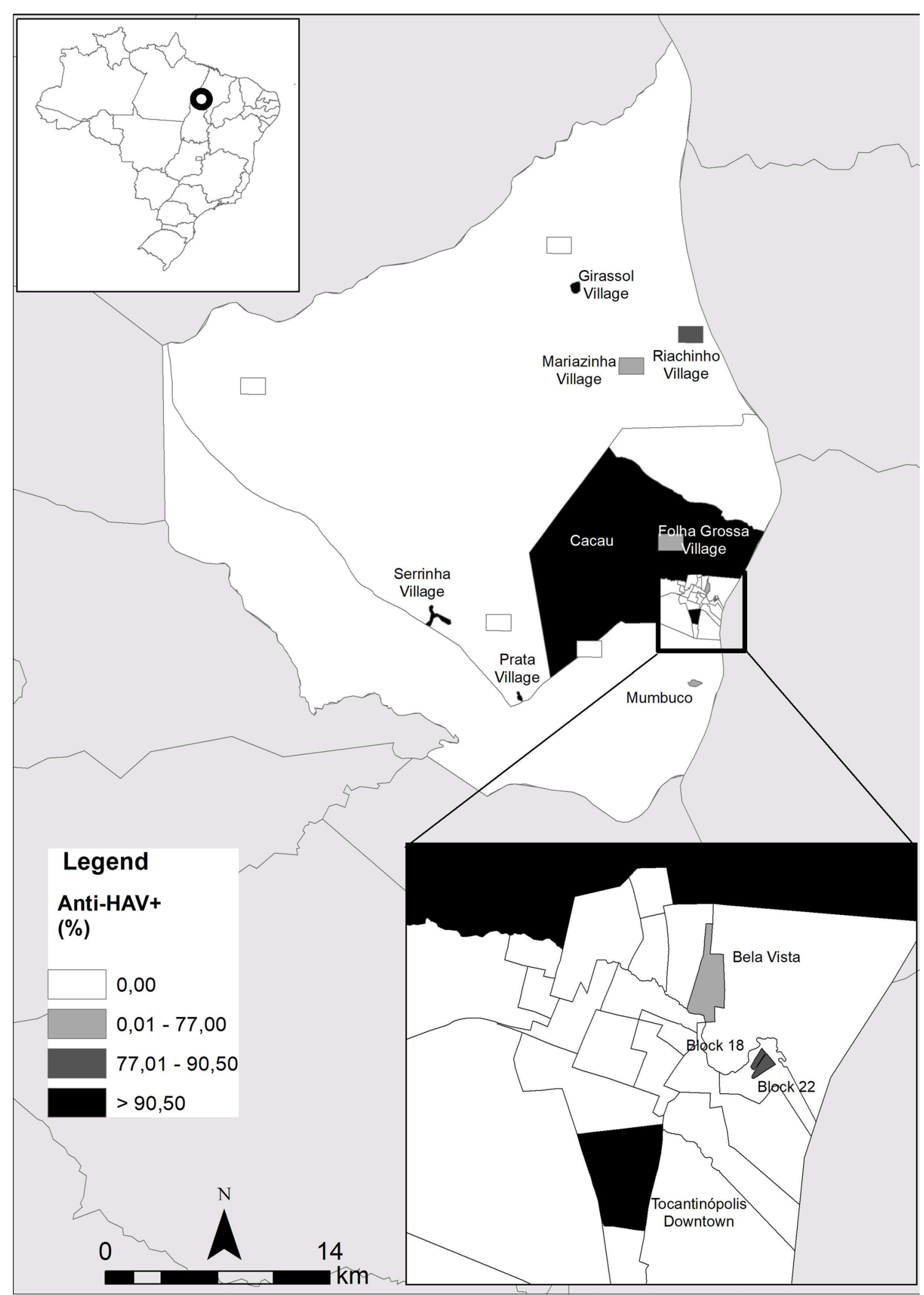

Fig. 1 Prevalence of cases of previous HAV infection (total anti-HAV) according site of recruitment in Eastern Amazon 


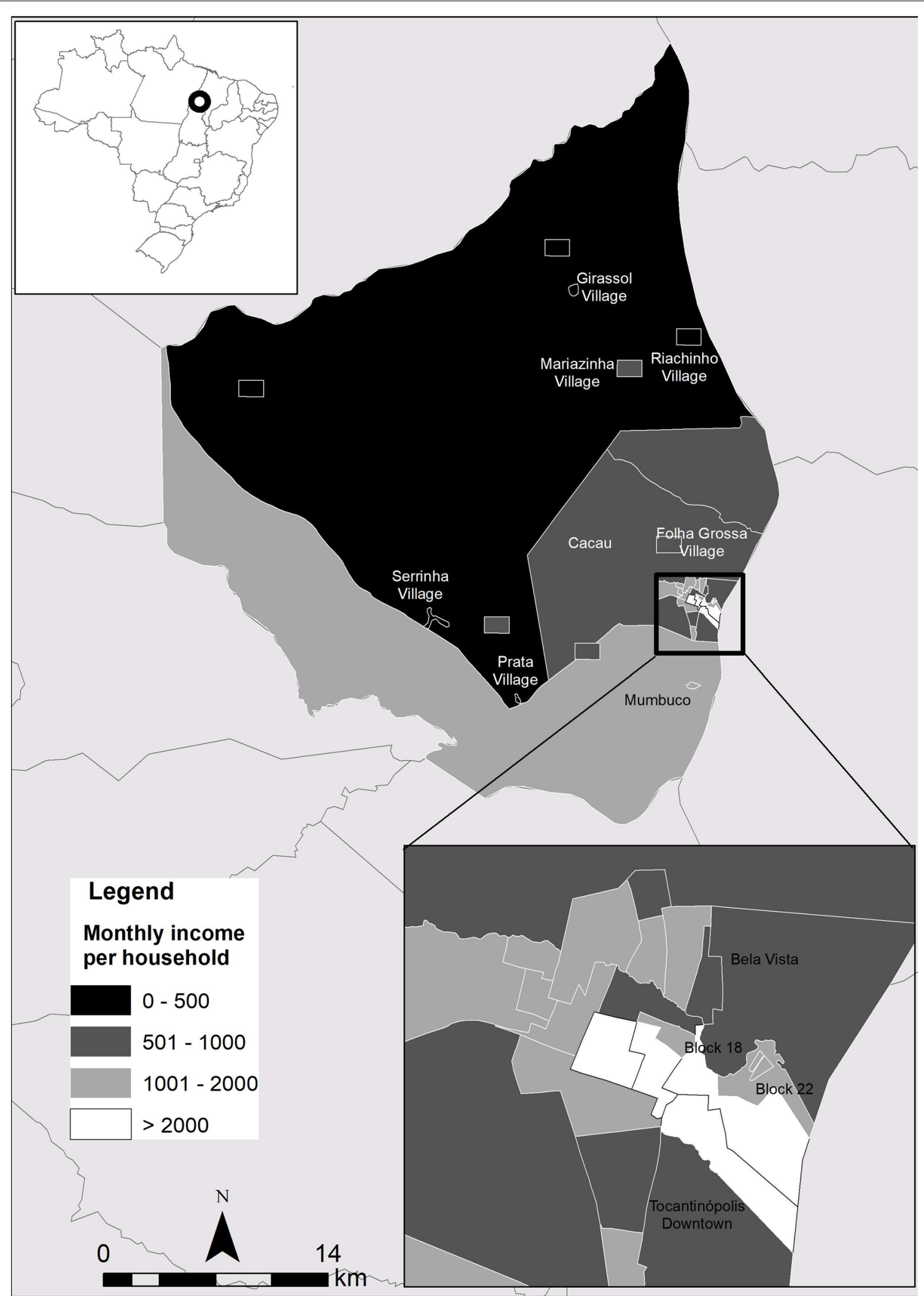

Fig. 2 Distribution of monthly income per household according site of recruitment in Eastern Amazon 
Taiwan. This is the result of three dose schedule vaccination in indigenous children aging between 15 months to 12 years old in 1995 and two dose regimens applied in nine cities close to indigenous population in 1998. In Australia, after the death of indigenous children with hepatitis A in Queensland, it was adopted vaccination in the region, which drastically reduced hepatitis A incidence from 237 to 9 cases between 1996 and 2003 [18].

Total anti-HAV prevalence was elevated in indigenous and non-indigenous population that have low monthly income. This demonstrates that HAV is common in low resource areas independent of ethnic group. Some studies demonstrated that HAV prevalence is associated to water access and monthly income [19-21]. HAV dispersion could increase the probability of outbreaks as reported in several communities [5, 22-24] and favor person-to-person transmission of HAV [25] that could be one of the main route of HAV dissemination among person that have strict contact, as happening in the indigenous culture.

Although it was found high total anti-HAV prevalence, the prevalence of IgM anti-HAV was low (1.7\%) and none of them had HAV RNA. Low prevalences of IgM anti-HAV were also found in Afro Brazilian isolated community (0.6\%) [26], risk group in Nigeria (1.5\%) [27] and plasma donors in China (0.7\%) [28]. However, data from South Africa's National Health Laboratory Service found 3.3\% of IgM anti-HAV between 2005 and 2015 [29] probably due to high risk observed in acute hepatitis cases. In indigenous community from North Brazil, more than $30 \%$ of acute HAV cases were found characterizing an outbreak [1] and a fatal course of hepatitis A was described in three indigenous children from western and northern Queensland, Australia, between 1993 and 1998 [30]. This situation demonstrates the importance of monitoring acute hepatitis cases in indigenous community.

Acute cases were high prevalent among males and those aging more than 40 years, where the disease is more severe. A study of hospitalization due to HAV in Taiwan found overall mortality rate of 16.8 per 1000 hospitalizations where high fatality rates was found in males and adjusted odds ratio for death rose by age and increased rapidly over 40 years of age [31]. Some studies showed that fatal cases occurred in individuals aging more than 40 years [32, 33]. High prevalence of acute cases was found in Folha Grossa village, indigenous tribe, that was not included as low monthly income, but it is near to urban area. A probable hypothesis is that one acute case had disseminated the virus in this community.

\section{Conclusion}

It was observed high overall anti-HAV prevalence in this study, but it did not differ between Indigenous and non-indigenous communities and most of acute cases was found in individuals aging more than 40 years reinforce the importance of universal HAV immunization to reduce the transmission of the virus in this group.

\section{Limitations}

The major limitation of the study is the lack of clinical data and risk factors of the population studied that could explain the high prevalence of hepatitis $\mathrm{A}$ in some communities.

\section{Acknowledgements}

The authors wish to thank Elisangela Ferreira da Silva for assistance in blood analysis and Tocantins Health Secretary for the assistance in blood sample collection.

\section{Authors' contributions}

VSP and LMV designed the study; HMC, JCM, GMO, LPS, VAM carried out laboratory analyses; VSP, FAPM, GMO, LMV reviewed the data, conducted statistical analyses and interpreted the results, MAFMM, ARR, RG carried out map analysis and interpreted the results, VSP and LMV wrote the first draft of the paper; all authors critically reviewed the manuscript. All authors read and approved the final manuscript.

\section{Funding}

This research was supported by the Fundação de Amparo a Pesquisa do Estado do Rio de Janeiro (FAPERJ), Brazilian National Counsel of Technological and Scientific Development (CNPq), Coordination for the Improvement of Higher Education Personnel (CAPES) and the Oswaldo Cruz Foundation (FIOCRUZ). They had no role in designing the study and collection, analysis, and interpretation of data and in writing the manuscript.

\section{Availability of data and materials}

The datasets generated and/or analysed during the current study are not publicly available due to confidenciality and privacity requested by Ethics Committee and Institution that allowed the recruitment of volunteers but are available from the corresponding author on reasonable request.

\section{Ethics approval and consent to participate}

All procedures performed in studies involving human participants were in accordance with the ethical standards of the institutional and/or national research committee (include name of committee + reference number) and with the 1964 Helsinki declaration and its later amendments or comparable ethical standards. Study was approved by Research Ethics Committee and the National Research Ethics Commission (CAAE: 32789914.6.0000.5248). Written informed consent was obtained from all individual participants included in the study.

\section{Consent for publication}

Not applicable.

\section{Competing interests}

The authors declare that they have no competing interests.

\section{Author details}

${ }^{1}$ Molecular Virology Laboratory, Oswaldo Cruz Institute, FIOCRUZ, Rio de Janeiro, Brazil. ${ }^{2}$ Federal University of Tocantins, UFT, Tocantins, Brazil. ${ }^{3}$ Cancer Nacional Institute, INCA, Rio de Janeiro, Brazil. ${ }^{4}$ Laboratory of Viral Hepatitis, Oswaldo Cruz Institute, FIOCRUZ, Helio and Peggy Pereira Pavillion, Ground Floor, Room B09, FIOCRUZ Av. Brasil, 4365 - Manguinhos, Rio de Janeiro 210360-040, Brazil. ${ }^{5}$ Hepatology Research Group, University of Plymouth, Plymouth, Devon, UK. ${ }^{6}$ Laboratory of Information in Health, Institute of Communication and Technological and Scientific Information in Health (ICICT), FIOCRUZ, Rio de Janeiro, Brazil. 
Received: 21 June 2020 Accepted: 22 September 2020

Published online: 29 September 2020

\section{References}

1. Nunes HM, Soares Mdo C, Silva HM. Hepatitis A virus infection in Amerindian area in the east Brazilian Amazon. Rev Soc Bras Med Trop. 2004:37(Suppl 2):52-6.

2. Romero-Sandoval N, Cifuentes L, León G, Lecaro P, Ortiz-Rico C, Cooper $P$, Martín M. High rates of exposures to waterborne pathogens in indigenous communities in the Amazon region of Ecuador. Am J Trop Med Hyg. 2019;101(1):45-50.

3. Albuquerque FA. Os Apinayé: informações sócio-históricas. Revista de Estudos e Pesquisas, FUNAl, Brasília. 2007:4(2):199-21919.

4. Brazilian Geographic and Statistics Institute. IBGE. Indigenous in the 2010 population census. https://indigenas.ibge.gov.br/images/indigenas/ estudos/indigena_censo2010.pdf. Accessed 26 Oct 2017.

5. Villar LM, Esteves da Costa Mdo C, de Paula VS, Gaspar AM. Hepatitis A outbreak in a public school in Rio de Janeiro, Brazil. Mem Inst Oswaldo Cruz. 2002;97(3):301-5.

6. Gabster A, Pascale JM, Cislaghi B, Francis SC, Weiss HA, Martinez A, Ortiz A, Herrera M, Herrera G, Gantes C, Quiel Y, Ríos A, Campbell E, Mayaud P. High prevalence of sexually transmitted infections, and high-risk sexual behaviors among indigenous adolescents of the Comarca Ngäbe-Buglé, Panama. Sex Transm Dis. 2019;46(12):780-7.

7. Brasil. IBGE. Censo Demográfico, 2010. Disponível em: www.ibge.gov.br. Acesso em 19 nov 2019

8. Villar LM, de Paula VS, Diniz-Mendes L, Lampe E, Gaspar AM. Evaluation of methods used to concentrate and detect hepatitis A virus in water samples. J Virol Methods. 2006;137(2):169-76.

9. de Paula VS, Diniz-Mendes L, Villar LM, Luz SL, Silva LA, Jesus MS, da Silva NM, Gaspar AM. Hepatitis A virus in environmental water samples from the Amazon Basin. Water Res. 2007;41:1169-76.

10. Tourinho RS, Almeida CR, Lemos AS, Gardinali NR, Vieira YR, Schmidt-Chanasit J, De Paula VS. Application of synthetic standard curves for absolute quantification of hepatitis A and E by real-time PCR. J Genet Genome Res. 2015;2:013.

11. Lafer MM, de Moraes-Pinto MI, Weckx LY. Prevalence of antibodies against hepatitis A virus among the Kuikuro and Kaiabi Indians of Xingu National Park, Brazil. Rev Inst Med Trop Sao Paulo. 2007;49(3):155-7.

12. Black FL, Jacobson DL. Hepatitis A antibody in an isolated Amerindian tribe fifty years after exposure. J Med Virol. 1986;19:19-211.

13. de Paula VS, Arruda ME, Vitral CL, Gaspar AM. Seroprevalence of vira hepatitis in riverine communities from the Western Region of the Brazilian Amazon Basin. Mem Inst Oswaldo Cruz. 2001;96(8):1123-8.

14. Mantovani SA, Delfino BM, Martins AC, Oliart-Guzmán H, Pereira TM, Branco FL, Braña AM, Filgueira-Júnior JA, Santos AP, Arruda RA, Guimarães AS, Ramalho AA, Oliveira CS, Araújo TS, Arróspide N, Estrada CH, Codeço $C T$, da Silva-Nunes M. Socioeconomic inequities and hepatitis A virus infection in Western Brazilian Amazonian children: spatial distribution and associated factors. BMC Infect Dis. 2015;15:428.

15. Pereira TM, Mantovani SA, Branco FL, Braña AM, Oliart-Guzmán H, Delfino BM, Martins AC, Araújo TS, Oliveira CS, Muniz PT, da Silva-Nunes M. Hepatitis A seroprevalence in preschool children in Assis Brazil, Acre, Brazil, in 2003 and 2010. Int Health. 2016;8(2):132-41.

16. Lin DB, Tsai TP, Yang CC, Wang HM, Yuan SC, Cheng MH, You SL, Chen CJ. Current seroprevalence of hepatitis A virus infection among kindergarten children and teachers in Taiwan. Southeast Asian J Trop Med Public Health. 2000;31(1):25-8.
17. Tsou TP, Liu CC, Huang JJ, Tsai KJ, Chang HF. Change in hepatitis A epidemiology after vaccinating high risk children in Taiwan, 1995-2008. Vaccine. 2011:29(16):2956-61.

18. Hanna JN, Hills SL, Humphreys JL. Impact of hepatitis A vaccination of Indigenous children on notifications of hepatitis A in north Queensland. Med JAust. 2004;181(9):482-5.

19. Luiz RR, Almeida RM, Almeida RT, de Almeida LM. The relation between anti-hepatitis $A$ virus antibodies and residence water access in Rio de Janeiro. Brazil Int J Hyg Environ Health. 2003;206(6):575-82.

20. Zago-Gomes MP, Stantolin GC, Perazzio S, Aikawa KH, Gonçalves CS, Pereira FE. Prevalence of anti-hepatits A antibodies in children of different socioeconomic conditions in Vila Velha. ES Rev Soc Bras Med Trop. 2005;38(4):285-9.

21. Chung GE, Yim JY, Kim D, Lim SH, Park MJ, Kim YS, Yang SY, Yang Jl, Cho $\mathrm{SH}$. Seroprevalence of hepatitis a and associated socioeconomic factors in young healthy Korean adults. Gut Liver. 2011;5(1):88-92.

22. Santos DR, Villar LM, Paula VS, Lima GS, Gaspar AM. Hepatitis A virus subgenotypes dissemination during a community outbreak in a surrounding region of Rio de Janeiro. Mem Inst Oswaldo Cruz. 2008;103(3):254-8.

23. Juniastuti, Wahyuddin D, Nihayatussa'adah, Amin M, Yamani LN, Utsumi T, Sustini F, Lusida MI. Analysis of genetic and serology of hepatitis A virus infection during and after outbreak in two junior high schools in Surabaya, Indonesia. J Med Virol. 2019;91(6):1048-1055.

24. Amado LA, Villar LM, de Paula VS, Pinto MA, Gaspar AM. Exposure to multiple subgenotypes of hepatitis A virus during an outbreak using matched serum and saliva specimens. J Med Virol. 2011;83(5):768-75.

25. Lima LR, De Almeida AJ, Tourinho Rdos S, Hasselmann B, Ximenez LL, De Paula VS. Evidence of hepatitis A virus person-to-person transmission in household outbreaks. PLoS ONE. 2014;9(7):e102925.

26. Kozlowski AG, Motta-Castro AR, Nascimento LB, Silva AM, Teles SA, Villar LM, Gaspar AM, Martins RM. Prevalence of hepatitis A virus infection in Afro-Brazilian isolated communities in Central Brazil. Mem Inst Oswaldo Cruz. 2007;102(1):121-3.

27. Ogefere HO, Egbe CA. Seroprevalence of IgM antibodies to hepatitis A virus in at-risk group in Benin City, Nigeria. Libyan J Med. 2016;11:31290.

28. Han T, Li C, Zhang Y, Wang Y, Wu B, Ke L, Liu G, Li L, Liu Y, Liu Z. The prevalence of hepatitis A virus and parvovirus B19 in source-plasma donors and whole blood donors in China. Transfus Med. 2015:25(6):406-10.

29. Haeri Mazanderani A, Motaze NV, McCarthy K, Suchard M, du Plessis NM. Hepatitis A virus seroprevalence in South Africa-estimates using routine laboratory data, 2005-2015. PLoS ONE. 2019;14(6):e0216033.

30. Hanna JN, Warnock TH, Shepherd RW, Selvey LA. Fulminant hepatitis $A$ in indigenous children in north Queensland. Med J Aust. 2000;172(1):19-211.

31. Chen CM, Chen SC, Yang HY, Yang ST, Wang CM. Hospitalization and mortality due to hepatitis A in Taiwan: a 15-year nationwide cohort study. J Viral Hepat. 2016;23(11):940-5.

32. Maki Y, Kimizuka Y, Sasaki H, Yamamoto T, Hamakawa Y, Tagami Y, Miyata J, Hayashi N, Fujikura Y, Kawana A. Hepatitis A virus-associated fulminant hepatites with human immunodeficiency virus coinfection. J Infect Chemother. 2020;26(2):282-5.

33. Yoshida Y, Okada Y, Suzuki A, Kakisaka K, Miyamoto Y, Miyasaka A, Takikawa Y, Nishizawa T, Okamoto H. Fatal acute hepatic failure in a family infected with the hepatitis A virus subgenotype IB: a case report. Medicine (Baltimore). 2017:96(35):e7847.

\section{Publisher's Note}

Springer Nature remains neutral with regard to jurisdictional claims in published maps and institutional affiliations. 